\title{
REPORT OF AN EXCURSION TO HORSLEY AND NETLEY HEATH.
}

\author{
Saturday, May 23RD, I9I4.
}

By The President (G. W. Young, F.G.S.), Director of the Excursion.

ON arrival at Horsley Station the party, numbering about 30 , walked westward over London Clay by the footpath which skirts the south side of the railway to West Horsley. Proceeding through this scattered village and passing over the narrow outcrop of the Reading Beds, which here make no feature, the Chalk is reached just before the crossing of the Leatherhead and Dorking road. At Wix's Farm close by, in a small, deep, dirty and much overgrown pit the Director found four Marsupites plates in 1906 , thus proving the zone.

A short distance south of this is Coombs Pit, extensively worked formerly, but now only occasionally. At its farther end is a rectangular inner pit with walls about 50 feet deep. There are two sets of strong joints running roughly N.W. to S.E. and N.E. to S.W. Owing to this the faces are smooth and almost vertical. The Chalk is white and hard with well marked bedding planes and nodular flint bands at varying intervals. Not far from the top is a thick yellow bed. It is fairly fossiliferous and has yielded a characteristic fauna of the upper part of the $M$. cor. anguinum zone. The commonest fossil is Conulus ( $=$ Echinoconus $=$ Galerites $)$ conicus, both the conical and tumid varieties being present, and many of these bear adnate Polyzoa. Micrasters and Brachiopods are rather scarce. It is possible there is a capping of Marsupites zone in the inaccessible top part of this pit.

The party next walked southward over rising ground for about a mile to Pebble Hill, where there is a small tertiary outlier. There is no section to be seen, but the practised eye of Mr. G. Barrow soon detected the presence of mottled Reading Clay in the road banks.

Beyond Pebble Hill the road drops sharply about roo ft. into a dry chalk valley and then rises again on to the broad expanse of Netley Heath, sloping up to about $620 \mathrm{ft}$. O.D. Here there is a large spread of "Sands of doubtful age" of the Survey, but regarded by Mr. W. P. D. Stebbing* as being probably Pliocene Two pits were visited, but owing to the threatening rain only a hurried inspection was made, and no fossils were found. The characteristic ferruginous sandy grit containing flint pebbles was, however, duly noted.

\footnotetext{
* Proc. Geol. Assoc., vol. xvi, p. 524.
} 
The return journey was made via Rails Hatch and then by bridle road through well-wooded country to West Horsley Church, where the main road was taken to the Duke of Wellington Inn at East Horsley for tea. Pole Pit, close by, was pointed out as having yielded plates of Marsupites, but it is so dirty and thickly shaded by trees that finding them is a difficult matter.

Both time and rain prevented a visit to Rowbarns Pit, another fossiliferous exposure in the $M$. cor. anguinum zone, about halfa-mile south of East Horsley Church, and the party returned to town by the 7.45 train. Mr. T. W. Reader acted as Secretary of this Excursion.

\section{REFERENCES.}

Geological Survey Map, $\mathrm{I}$ in., Old Series, Sheet 8, Drift Ed.

I 872, Whit Kakr, W., Geol. Surv. Mem., vol. iv.

1887. French, H. H. - "Excursion to Gomshall, Netiey Heath and Clandon." Proc. Geol. Assoc., vol. x, p. 182.

1900. Stebbing, W. P. D.- "Excursion to Netley Heath and Newlands Corner." Ibid., vol. xvi, p. 524.

1907. YounG, G. W.- "The Chalk Area of Western Surrey." Ibid., vol. xx, p. 422 .

\section{REPORT OF AN EXCURSION TO CHARMOUTH AND LYME REGIS.}

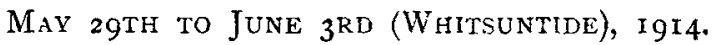

By The President (George W. Young, F.G.S.) and W. D. LANG, M.A., F.G.S., Directors of the Excursion.

The Headquarters were at the Bow House, Lyme Regis. Mr. A. H. Williams acted as the Excursion Secretary.

May 3oth.-Report BY Mr. LANG.

A PARTy of twenty assembled on the jetty at the bottom of Broad Street, and, embarking in boats, proceeded to examine from the sea the general geological features of the cliffs east of Lyme. Unfortunately a rainy mist hid the tops of the cliffs, but the lower parts were quite visible, and the whole succession from the angulatus-zone to the top of the Belemnite Marls was visible as each bed in turn, owing to the generally easterly dip, descended to the beach.

Church Cliffs were first passed, consisting of limestones with partings of shale, in the angulatus- and bucklandi-zones, bent into an anticline. Beneath Lyme Church a wall has been built against the cliff in the hope that thus the continual falling of the cliff (aggravated by the destruction and removal in the past of 